\title{
Correction: Neonatal brain injuries in England: population-based incidence derived from routinely recorded clinical data held in the National Neonatal Research Database
}

Gale C, Statnikov Y, Jawad S, et al. Neonatal brain injuries in England: population-based incidence derived from routinely recorded clinical data held in the National Neonatal Research Database. Arch Dis Childhood - Fetal and Neonatal Edition 2018;103:F301-6.

The authors have identified an error in data extraction that resulted in the following: (1) the inclusion of babies with Grade 1 HIE who did not receive therapeutic hypothermia; (2) the exclusion of babies with central nervous system infection after 48 hours after birth. A data transcription error resulted in incorrect numbers of exclusions. Therefore the following sections are corrected as outlined below.

\section{ABSTRACT RESULTS}

The results section of the Abstract should be as follows: 'In 2010, the lower estimate of the rate of 'Brain injuries occurring at or soon after birth' in England was 3.99 and the upper estimate was 4.66; in 2015, the rate was 4.52 (4.36 to 4.68). For preterm infants, the population incidence in 2015 was 24.45 (23.12 to 25.85) and for term infants 2.91 (2.78 to 3.05). Hypoxic ischaemic encephalopathy was the largest contributor to term brain injury and intraventricular/periventricular haemorrhage was the largest contributor to preterm brain injury.'

\section{RESULTS}

The first and second paragraph of the Results section of the manuscript are corrected to 'The number of infants admitted to neonatal units contributing data to the NNRD increased from 64375 in 2010 to 88785 in 2015; the annual rate of brain injuries after exclusions in England in 2010 was between 3.87 and 4.44 per 1000 live births; in 2015 to the rate was 4.52 (95\% CI 4.36 to 4.68 ) per 1000 live births (table 1); annual data for 2010 to 2015 are presented table 1.'

'The annual rate of brain injuries among term infants ( $\geq 37$ gestational weeks) in England in 2015 was 2.91 (95\% CI 2.78 to 3.05) per 1000 live term births; data for term infants born over the period 2010 to 2015 are presented in table 2 . The annual rate of brain injuries among preterm infants $(<37$ gestational weeks) in England in 2015 was 24.45 (95\% CI 23.12 to 25.85) per 1000 live preterm births; data for preterm infants between 2010 and 2015 can be found in table 3.'

\section{DISCUSSION}

The third paragraph of the Discussion section of the manuscript is corrected to: 'The novelty of the measure brain injuries that occur at or soon after birth, and the source of the data, the NNRD which is formed from routinely recorded clinical information makes it necessary to consider how incidence rates of individual conditions we report compare with other published data. The annual incidence rates for moderate and severe HIE of between 1.6 and 1.9 per 1000 live births are consistent with other reported rates of neonatal encephalopathy of between 0.77-3.8 per 1000 live births in low neonatal mortality regions such as the United Kingdom and the United States of America. When considering neonatal intracranial haemorrhage, published data commonly reported incidence separately for term and preterm infants. A 30-year-old, single centre study from the USA reported a regional incidence of 2.7 per 10000 live births for symptomatic intracranial haemorrhage in term infants, which is comparable with the population incidence of 1.5 to 1.9 per 10000 term births that we report. For preterm infants born at 22-31 weeks gestational age, comparable populationlevel incidence data for intraventricular/periventricular haemorrhage from the national French EPIPAGE cohort are 3.8\% for grade 3\% and 3.3\% for grade four intra/periventricular haemorrhage. In the same gestational age band, we report annual incidence rates between $5.8 \%$ and $6.1 \%$ for a composite including grades 3 and 4 intraventricular/periventricular haemorrhage. We report annual incidence rates for neonatal or perinatal stroke of between 0.11 and 0.15 per 1000 live births, which is similar to the estimated minimum incidence rate of 0.10 per 1000 live births reported by a prospective, population-based study from Canada. The annual incidence of neonatal central nervous system infection we report of 0.56 to 0.82 per 1000 live births is similarly in agreement with the population-level incidence rate for neonatal meningitis in England and Wales of 0.39 per 1000 live births (1996-1997) reported by the British Paediatric Surveillance Unit (BPSU). Similarly, annual rates of bilirubin encephalopathy reported here of between 0.3 and 1.2 per 100000 live births are comparable with BPSU population surveillance rates of 0.9 per 100000 live births (2003-2005). EPIPAGE 2 (2011) report an incidence among 23 to 34 gestational week infants of $1.8 \%$ for cystic 
periventricular leukomalacia; in the same gestational age group, we report annual rates of between $1.13 \%$ and $1.27 \%$. Finally population-based studies of neonatal seizures over the last 30 years report incidence rates between 1.8 and 3.5 per 1000 live births, results that are again in keeping with our annual rates of 1.9 to 2.2 per 1000 live births.'

The following 4 tables (tables $1-4$ ) are corrected as below.

Table 1 Infants in England (all gestational ages) with a diagnosis of brain injury to before and after exclusion of conditions leading to brain injury prior to birth; data for 2010 and 2011 are adjusted to account for the incomplete coverage of the NNRD during those years; from 2012 onwards the NNRD has complete population coverage of neonatal admissions in England so no adjustment was necessary and data are presented as a rate $(95 \% \mathrm{Cl})$

\begin{tabular}{|c|c|c|c|c|c|c|c|c|c|}
\hline Year & $\begin{array}{l}\text { Infants } \\
\text { recorded } \\
\text { in the } \\
\text { NNRD }\end{array}$ & $\begin{array}{l}\text { Live } \\
\text { births in } \\
\text { England }\end{array}$ & $\begin{array}{l}\text { Infants } \\
\text { with brain } \\
\text { injury to } \\
\text { before } \\
\text { exclusions }\end{array}$ & Exclusions & $\begin{array}{l}\text { Infants } \\
\text { with brain } \\
\text { injury } \\
\text { to after } \\
\text { exclusions }\end{array}$ & $\begin{array}{l}\text { Infants with } \\
\text { brain injury } \\
\text { adjusted for } \\
\text { incomplete } \\
\text { NNRD } \\
\text { coverage }\end{array}$ & $\begin{array}{l}\text { Infants with } \\
\text { brain injury } \\
\text { adjusted for } \\
\text { incomplete } \\
\text { NNRD } \\
\text { coverage } \\
\text { to after } \\
\text { exclusions }\end{array}$ & $\begin{array}{l}\text { Rate of } \\
\text { brain } \\
\text { injuries per } \\
1000 \text { live } \\
\text { births }\end{array}$ & $\begin{array}{l}\text { Brain } \\
\text { injuries } \\
\text { per } 1000 \\
\text { live births } \\
\text { to after } \\
\text { exclusions } \\
(95 \% \mathrm{Cl})\end{array}$ \\
\hline 2010 & 64375 & 687007 & 2594 & 59 & 2535 & 2743 to 3202 & 2660 to 3051 & 3.99 to 4.66 & 3.87 to 4.44 \\
\hline 2011 & 72678 & 688120 & 2906 & 65 & 2841 & 2963 to 3159 & 2889 to 3055 & 4.31 to 4.59 & 4.20 to 4.44 \\
\hline 2012 & 78980 & 694241 & 2950 & 76 & 2874 & not adjusted & not adjusted & $\begin{array}{l}4.25 \\
(4.10,4.41)\end{array}$ & $\begin{array}{l}4.14 \\
(3.99,4.29)\end{array}$ \\
\hline 2013 & 80222 & 664517 & 2966 & 62 & 2904 & not adjusted & not adjusted & $\begin{array}{l}4.46 \\
(4.31,4.63)\end{array}$ & $\begin{array}{l}4.37 \\
(4.21,4.53)\end{array}$ \\
\hline 2014 & 85013 & 661496 & 3097 & 56 & 3041 & not adjusted & not adjusted & $\begin{array}{l}4.68 \\
(4.52,4.85)\end{array}$ & $\begin{array}{l}4.60 \\
(4.44,4.76)\end{array}$ \\
\hline 2015 & 88931 & 664399 & 3055 & 54 & 3001 & not adjusted & not adjusted & $\begin{array}{l}4.60 \\
(4.44,4.76)\end{array}$ & $\begin{array}{l}4.52 \\
(4.36,4.68)\end{array}$ \\
\hline
\end{tabular}

Table 2 Term ( $\geq 37$ gestational weeks) infants in England with a diagnosis of brain injury to before and after exclusion of conditions leading to brain injury prior to birth; data for 2010 and 2011 are adjusted to account for the incomplete coverage of the NNRD during these years; from 2012 onwards the NNRD has complete population coverage of neonatal admissions in England so no adjustment was necessary and data are presented as a rate $(95 \% \mathrm{Cl})$

\begin{tabular}{lllllll}
\hline & $\begin{array}{l}\text { Term } \\
\text { infants } \\
\text { recorded } \\
\text { in the } \\
\text { NNRD }\end{array}$ & $\begin{array}{l}\text { Term live } \\
\text { births in } \\
\text { England }\end{array}$ & $\begin{array}{l}\text { Term infants } \\
\text { with brain } \\
\text { injury to } \\
\text { before } \\
\text { exclusions }\end{array}$ & $\begin{array}{l}\text { Term infants with brain injury } \\
\text { adjusted for incomplete NNRD } \\
\text { coverage }\end{array}$ & $\begin{array}{l}\text { Term infants } \\
\text { with brain } \\
\text { injury to after } \\
\text { adjustment } \\
\text { and exclusions }\end{array}$ & $\begin{array}{l}\text { Rate of brain } \\
\text { injuries per } \begin{array}{l}1000 \\
\text { term live births to } \\
\text { after exclusions } \\
(95 \% \text { Cl) }\end{array}\end{array}$ \\
\hline 2010 & 35415 & 627357 & 1478 & 1597 to 1795 & 1562 to 1756 & 2.49 to 2.80 \\
2011 & 41429 & 630419 & 1716 & 1786 to 1845 & 1740 to 1798 & 2.76 to 2.85 \\
2012 & 46200 & 640787 & 1714 & not adjusted & 1661 & $2.59(2.47,2.72)$ \\
2013 & 47935 & 612816 & 1754 & not adjusted & 1713 & $2.80(2.67,2.93)$ \\
2014 & 51945 & 607972 & 1848 & not adjusted & 1804 & $2.97(2.83,3.11)$ \\
\hline 2015 & 55045 & 609076 & 1808 & not adjusted & 1771 & $2.91(2.78,3.05)$ \\
\hline
\end{tabular}

Table 3 Preterm (<37 gestational weeks) infants in England with a diagnosis of brain injury to before and after exclusion of conditions leading to brain injury prior to birth; data for 2010 and 2011 are adjusted to account for the incomplete coverage of the NNRD during these years; from 2012 onwards the NNRD has complete population coverage of neonatal admissions in England so no adjustment was necessary and data are presented as a rate $(95 \% \mathrm{Cl})$

\begin{tabular}{lllllll}
\hline & $\begin{array}{l}\text { Preterm } \\
\text { infants } \\
\text { recorded } \\
\text { in the } \\
\text { NNRD }\end{array}$ & $\begin{array}{l}\text { Preterm } \\
\text { live births } \\
\text { in England }\end{array}$ & $\begin{array}{l}\text { Preterm } \\
\text { infants with } \\
\text { brain injury } \\
\text { to before } \\
\text { exclusions }\end{array}$ & $\begin{array}{l}\text { Preterm infants with } \\
\text { brain injury adjusted } \\
\text { for incomplete NNRD } \\
\text { coverage }\end{array}$ & $\begin{array}{l}\text { Preterm infants } \\
\text { with brain injury } \\
\text { after adjustment } \\
\text { and exclusions }\end{array}$ & $\begin{array}{l}\text { Rate of brain injuries } \\
\text { per } 1000 \text { preterm } \\
\text { live births to after } \\
\text { exclusions (95\% Cl) }\end{array}$ \\
\hline 2010 & 28960 & 43928 & 1116 & 1203 to 1238 & 1173 to 1208 & 26.71 to 27.51 \\
\hline 2011 & 31249 & 44547 & 1190 & 1219 to 1234 & 1197 to 1213 & 26.88 to 27.22 \\
2012 & 32752 & 49949 & 1236 & not adjusted & 1213 & $24.28(22.96,25.69)$ \\
2013 & 32264 & 48844 & 1212 & not adjusted & 1191 & $24.38(23.04,25.81)$ \\
2014 & 33036 & 49379 & 1249 & not adjusted & 1237 & $25.05(23.69,26.49)$ \\
2015 & 33740 & 50308 & 1247 & not adjusted & 1230 & $24.45(23.12,25.85)$ \\
\hline
\end{tabular}


Table 4 Infants in England with conditions leading to brain injury at or soon after birth; infants can be diagnosed with more than one condition so the sum of conditions for each year will not match data given in tables 1-3; P/IVH: periventricular/intraventricular haemorrhage, $\mathrm{Cl}$ : confidence interval

\begin{tabular}{|c|c|c|c|c|c|}
\hline \multirow[b]{2}{*}{ Condition } & & \multicolumn{4}{|l|}{ Year } \\
\hline & & 2012 & 2013 & 2014 & 2015 \\
\hline \multirow[t]{4}{*}{ Seizures } & Number of cases & 1445 & 1432 & 1360 & 1249 \\
\hline & $\begin{array}{l}\text { Rate per } 1000 \text { live } \\
\text { births }(95 \% \mathrm{Cl})\end{array}$ & 2.1 (2.0 to 2.1$)$ & 2.2 (2.1 to 2.3 ) & 2.1 (2.0 to 2.2 ) & $1.9(1.8$ to 2.0$)$ \\
\hline & Number of term cases & 1065 & 1036 & 1009 & 919 \\
\hline & $\begin{array}{l}\text { Number of preterm } \\
\text { cases }\end{array}$ & 378 & 396 & 351 & 330 \\
\hline \multirow{7}{*}{$\begin{array}{l}\text { Intracranial } \\
\text { haemorrhage }\end{array}$} & Number of cases & 754 & 677 & 689 & 726 \\
\hline & $\begin{array}{l}\text { Rate per } 1000 \text { live } \\
\text { births }(95 \% \mathrm{Cl})\end{array}$ & 1.1 (1.0 to 1.2$)$ & $1.0(0.9$ to 1.1$)$ & $1.0(1.0$ to 1.1$)$ & $1.1(1.0$ to 1.2$)$ \\
\hline & Number of term cases & 110 & 94 & 104 & 117 \\
\hline & $\begin{array}{l}\text { Rate per } 10000 \\
\text { term births }(95 \% \mathrm{Cl})\end{array}$ & 1.7 (1.4 to 2.1$)$ & $1.5(1.3$ to 1.9$)$ & 1.7 (1.4 to 2.1$)$ & 1.9 (1.6 to 2.3$)$ \\
\hline & $\begin{array}{l}\text { Number of preterm } \\
\text { cases }\end{array}$ & 644 & 583 & 585 & 609 \\
\hline & $\begin{array}{l}\text { Severe } \mathrm{P} / \mathrm{IVH}<32 \\
\text { weeks gestation }\end{array}$ & 483 & 445 & 468 & 452 \\
\hline & $\begin{array}{l}\text { Rate of severe } \mathrm{PI} \\
\text { IVH per } 1000 \text { live } \\
\text { births }<32 \text { weeks } \\
(95 \% \mathrm{Cl})\end{array}$ & $60.4(55.2$ to 66.0$)$ & 57.7 (52.6 to 63.4) & 61.1 (55.8 to 66.9$)$ & 58.3 (53.1 to 63.9) \\
\hline \multirow{4}{*}{$\begin{array}{l}\text { Perinatal/ } \\
\text { neonatal stroke }\end{array}$} & Number of cases & 77 & 100 & 88 & 90 \\
\hline & $\begin{array}{l}\text { Rate per } 1000 \text { live } \\
\text { births }(95 \% \mathrm{Cl})\end{array}$ & $0.11(0.09$ to 0.14$)$ & $0.15(0.12$ to 0.18$)$ & $0.13(0.11$ to 0.16$)$ & $0.14(0.11$ to 0.17$)$ \\
\hline & Number of term cases & 64 & 78 & 72 & 76 \\
\hline & $\begin{array}{l}\text { Number of preterm } \\
\text { cases }\end{array}$ & 13 & 22 & 16 & 14 \\
\hline \multirow{4}{*}{$\begin{array}{l}\text { Hypoxic- } \\
\text { ischaemic } \\
\text { encephalopathy }\end{array}$} & Number of cases & 1128 & 1161 & 1257 & 1243 \\
\hline & $\begin{array}{l}\text { Rate per } 1000 \text { live } \\
\text { births }(95 \% \mathrm{Cl})\end{array}$ & $1.6(1.5$ to 1.7$)$ & $1.7(1.6$ to 1.9$)$ & $1.9(1.8$ to 2.0$)$ & $1.9(1.8$ to 2.0$)$ \\
\hline & Number of term cases & 944 & 971 & 1044 & 1018 \\
\hline & $\begin{array}{l}\text { Number of preterm } \\
\text { cases }\end{array}$ & 184 & 190 & 213 & 225 \\
\hline \multirow{4}{*}{$\begin{array}{l}\text { Central nervous } \\
\text { system infection }\end{array}$} & Number of cases & 390 & 452 & 543 & 510 \\
\hline & $\begin{array}{l}\text { Rate per } 1000 \text { live } \\
\text { births }(95 \% \mathrm{Cl})\end{array}$ & $0.56(0.51$ to 0.62$)$ & $0.68(0.62$ to 0.75$)$ & 0.82 (0.76 to 0.89 ) & 0.77 (0.70 to 0.84$)$ \\
\hline & Number of term cases & 205 & 275 & 302 & 304 \\
\hline & $\begin{array}{l}\text { Number of preterm } \\
\text { cases }\end{array}$ & 185 & 177 & 241 & 206 \\
\hline \multirow{4}{*}{$\begin{array}{l}\text { Bilirubin } \\
\text { encephalopathy }\end{array}$} & Number of cases & 8 & 7 & 2 & 4 \\
\hline & $\begin{array}{l}\text { Rate per } 100000 \\
\text { live births }(95 \% \mathrm{Cl})\end{array}$ & 1.2 (0.6 to 2.3 ) & 1.1 (0.5 to 2.2$)$ & $0.3(0.1$ to 1.2$)$ & $0.6(0.2$ to 1.6$)$ \\
\hline & Number of term cases & 6 & 5 & 2 & 4 \\
\hline & $\begin{array}{l}\text { Number of preterm } \\
\text { cases }\end{array}$ & 2 & 2 & 0 & 0 \\
\hline \multirow{4}{*}{$\begin{array}{l}\text { Cystic } \\
\text { periventricular } \\
\text { leucomalacia }\end{array}$} & $\begin{array}{l}\text { Number of preterm } \\
\text { cases }\end{array}$ & 199 & 175 & 171 & 184 \\
\hline & $\begin{array}{l}\text { Rate per } 1000 \text { live } \\
\text { births }(95 \% \mathrm{Cl})\end{array}$ & $0.3(0.3$ to 0.3$)$ & $0.3(0.2$ to 0.3$)$ & $0.3(0.2$ to 0.3$)$ & $0.3(0.2$ to 0.3$)$ \\
\hline & $\begin{array}{l}\text { Number of cases at } \\
<34 \text { weeks gestation }\end{array}$ & 186 & 175 & 157 & 176 \\
\hline & $\begin{array}{l}\text { Rate per } 1000 \text { live } \\
\text { births<34 weeks } \\
\text { gestation }(95 \% \mathrm{Cl})\end{array}$ & 12.7 (11.0 to 14.7$)$ & 12.5 (10.7 to 14.4$)$ & 11.3 (9.7 to 13.3 ) & 12.4 (10.7 to 14.4$)$ \\
\hline
\end{tabular}

\section{OPEN ACCESS}

Open access This is an open access article distributed in accordance with the Creative Commons Attribution 4.0 Unported (CC BY 4.0) license, which permits others to copy, redistribute, remix, transform and build upon this work for any purpose, 
provided the original work is properly cited, a link to the licence is given, and indication of whether changes were made. See: https://creativecommons.org/licenses/by/4.0/.

(C) Author(s) (or their employer(s)) 2021. Re-use permitted under CC BY. Published by BMJ.

Arch Dis Child Fetal Neonatal Ed 2021;106:e2. doi:10.1136/fetalneonatal-2017-313707corr1

(D) Check for updates 